\title{
Advances in Nanocatalysts Mediated Biodiesel Production: A Critical Appraisal
}

\author{
Avinash P. Ingle *, Anuj K. Chandel *, Rafael Philippini, Sabrina Evelin Martiniano and \\ Silvio Silvério da Silva \\ Department of Biotechnology, Engineering School of Lorena, University of São Paulo, Estrada Municipal \\ do Campinho, s/n, Lorena, CEP- 12.602-810, São Paulo, Brazil; philippini@usp.br (R.P.); \\ sabrina@debiq.eel.usp.br (S.E.M.); silviosilverio@usp.br or silviosilverio@gmail.com (S.S.d.S.) \\ * Correspondence: avinashingle@usp.br or ingleavinash14@gmail.com (A.P.I.); \\ anuj10@usp.br or anuj.kumar.chandel@gmail.com (A.K.C.)
}

Received: 13 January 2020; Accepted: 4 February 2020; Published: 7 February 2020

check for updates

\begin{abstract}
The excessive consumption of petroleum resources leads to global warming, fast depletion of petroleum reserves, as well as price instability of gasoline. Thus, there is a strong need for alternative renewable fuels to replace petroleum-derived fuels. The striking features of an alternative fuel include the low carbon footprints, renewability and affordability at manageable prices. Biodiesel, made from waste oils, animal fats, vegetal oils, is a totally renewable and non-toxic liquid fuel which has gained significant attraction in the world. Due to technological advancements in catalytic chemistry, biodiesel can be produced from a variety of feedstock employing a variety of catalysts and recovery technologies. Recently, several ground-breaking advancements have been made in nano-catalyst technology which showed the symmetrical correlation with cost competitive biodiesel production. Nanocatalysts have unique properties such as their selective reactivity, high activation energy and controlled rate of reaction, easy recovery and recyclability. Here, we present an overview of various feedstock used for biodiesel production, their composition and characteristics. The major focus of this review is to appraise the characterization of nanocatalysts, their effect on biodiesel production and methodologies of biodiesel production.
\end{abstract}

Keywords: biodiesel; feedstock; nanocatalyst; magnetic nanocatalysts; catalysis

\section{Introduction}

Excessive consumption of gasoline, fast depletion, price instability and serious environmental damage are the principle issues that have called for the sustainable alternatives of gasoline. Liquid transportation biofuels such as biodiesel and bioethanol are promising renewable fuels that have low carbon footprints and have the potential to fulfill the continuously increasing energy demand. They are an eco-benign and non-toxic drop-in biofuel which is used in standard diesel engines. Biodiesel can be used directly without any modification or can be blended with conventional diesel in any ratio. Biodiesel produced from non-food sources offers an economic, robust alternative of petroleum-derived fuels. However, the production cost, availability of raw feedstock and process complications are among the main principle factors which strongly influence the biodiesel production at commercial level [1]. For biodiesel production, a wide range of feedstocks such as vegetable oils, oils from algae and microorganisms, seeds from energy crops (Jatropha curcus, Pongamia pinnata, etc.), and animal fat are used worldwide. Following biodiesel production methods such as pyrolysis, the supercritical fluid method, and transesterification are commonly used for biodiesel production. Amongst these methods, transesterification is the most widely used [2,3]. 
Biodiesel can be produced through triacylglycerides transesterification reactions using four different catalytic routes: (i) base-catalyzed processes, (ii) acid-catalyzed processes, (iii) enzyme-catalyzed processes, and (iv) use of supercritical conditions. Moreover, the advantages and disadvantages of all these different routes have been already discussed in several review articles [4,5]. As far as the homogeneous base-catalyzed process for biodiesel production is concerned, different bases such as sodium hydroxide $(\mathrm{NaOH})$, potassium hydroxide $(\mathrm{KOH})$, sodium methoxide $\left(\mathrm{NaOCH}_{3}\right)$, and sodium ethoxide $\left(\mathrm{NaOCH}_{2} \mathrm{CH}_{3}\right)$ are routinely used as the catalysts. However, there are many limitations associated with these base catalysts [6,7]. Similarly, there are a few drawbacks associated with acid-catalyzed processes [8]. Hence, in order to overcome the limitations of the above-mentioned two catalytic routes (i.e., base-catalyzed and acid-catalyzed processes), enzyme-catalyzed processes are being used as promising alternatives and more sustainable routes for biodiesel production [3,7]. In this context, lipases are effectively used as promising catalysts in biodiesel production, due to their higher specificity towards transesterification of triacylglycerides to fatty acid methyl esters (FAMEs) or fatty acid ethyl esters (FAEEs), compared to the various other conventional chemical catalysts commonly employed in industrial biodiesel production [8].

In addition to all these conventional catalytic routes, recently, nanotechnology-based biodiesel production has gained global interest because of the development of the most promising nanocatalysts [9]. Nanocatalysts have several advantages over traditional catalysts used in biodiesel production such as high reactivity, good selectivity, and the optimum yield. For biodiesel production, heterogeneous catalytic reactions seem more feasible because of the easy and fast recovery of catalysts from the reaction mixtures [10]. The nano-catalyst-mediated esterification process offers several unique advantages, for instance, an increased rate of mixing with reactants, saving of reaction times, and fast and easy separation from the reaction mixture. The basic inherent catalytic activity and selectivity can be easily regulated by altering the physical and chemical properties of the catalysts [11]. Alkaline-catalyzed methods ( $\mathrm{NaOH}, \mathrm{KOH})$, acid catalyzed methods $\left(\mathrm{HCl}, \mathrm{H}_{2} \mathrm{SO}_{4}\right)$ and enzyme- (lipase) catalyzed methods are in vogue. Lipases are heterogeneous biochemical catalysts that are exclusively produced by microorganisms. Homogeneous acid catalysts present some unique advantages over alkali-catalyzed methods.

In this paper, we discuss the various feedstocks used for biodiesel production and the conventional methods of biodiesel production using catalyst-assisted approaches (acid-catalyzed, alkaline catalyzed and lipase catalyzed). Specifically, the role of nanocatalysts and their symmetric correlation in biodiesel production has been presented in detail.

\section{Important Feedstocks Used in Biodiesel Production}

Biodiesel is usually produced from renewable feedstocks, such as vegetable oils, animal fats, greases, waste cooking oils, algae oils, oleaginous microorganisms, etc. [12-15]. Some of the important feedstocks commonly used for the production of biodiesel are shown in Figure 1. These sources contain a mixture of fatty acid-alkyl esters, which will be converted into biodiesel after the transesterification and esterification processes [15]. Generally, industrial production utilizes oil crops, mainly soybean, sunflower and rapeseed oils [16]. In 2018, technologies involving animal fat and waste oil provided about $6-8 \%$ of all biofuel output [17].

Biodiesel is considered as eco-friendly unlike petroleum-derived fuels because of lower sulfur and aromatic compounds contents [15]. Moreover, this biofuel is oxygenated, non-toxic, less polluted and biodegradable, and moreover, its use in engines does not require any adaptation [14]. The increase in population leads to a tremendous increase in energy demand and consequently, competition for agricultural lands and crops since the first-generation biodiesel uses edible oils [12]. The growing concern about food and environmental impacts encourages researchers to think about new and surplus available feedstocks, including non-edible oils, and biotechnological processes. Some of the important feedstocks commonly used in biodiesel production are discussed below: 


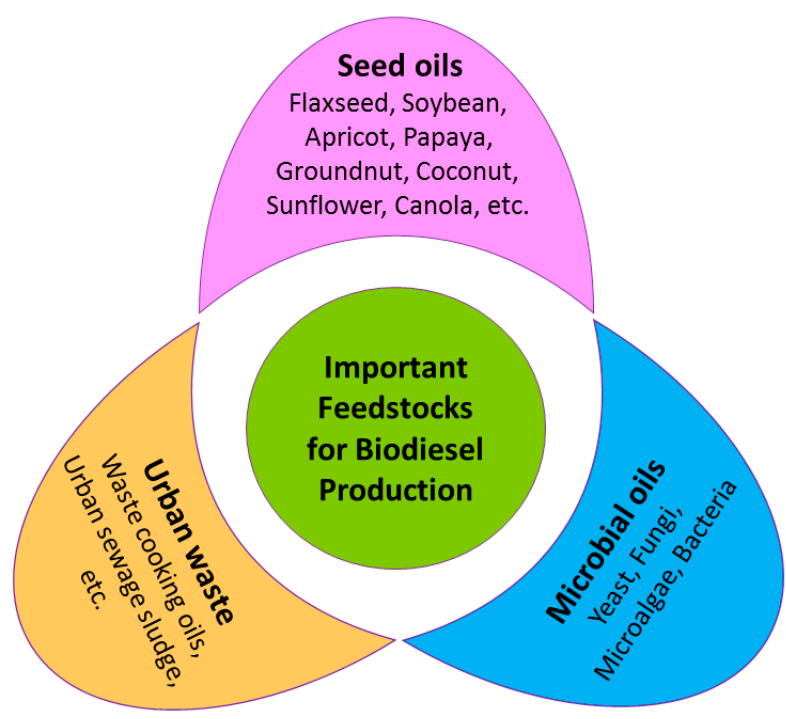

Figure 1. Some of the important feedstocks commonly used for the production of biodiesel.

\subsection{Seed Oils}

Seed oils are one of the most commonly used feedstocks for biodiesel production. However, not all seeds are able to act as feedstock for biodiesel production, since they need to have high quantities of lipids and large availability round the year [16], besides the presence of FAMEs in long-chain with more than $50 \%$ of unsaturated fatty acids [18]. Some of the seeds exhibit a huge variability in their oil composition depending on the variety of specific plant, for instance, sunflower oil, which contains either linoleic or oleic acid in high quantities [19]. Table 1 shows some of the vegetable species that have demonstrated the potential for biodiesel production and their fatty acid composition profile [19-25].

Table 1. Examples of oleaginous plants used in biodiesel production.

\begin{tabular}{|c|c|c|}
\hline Seed (Oil) & Fatty Acid Composition (\%) & Reference \\
\hline Flaxseed & $\begin{array}{l}\text { Linolenic (51.56), palmitic (5.7), stearic (5.6), oleic (20.66), linoleic (15.86), } \\
\text { arachidic }(0.2) \text {, g-linolenic }(0.23) \text { and behenic (0.18) acids; SFA (11.69) and UFA (88.31) }\end{array}$ & [19] \\
\hline Cascabela ovata & $\begin{array}{l}\text { Oleic (60), capric }(0.5) \text {, palmitoleic }(0.35) \text {, palmitic }(19.53) \text {, linoleic }(6.78) \text {, stearic (11.50), } \\
\text { oleic (59.30) and arachidic (1.56) acids }\end{array}$ & [20] \\
\hline Spindletree & $\begin{array}{l}\text { Linoleic (49.3), palmitoleic (2.0), palmitic (14.5), oleic (29.8), stearic (3.1), } \\
\text { 11-eicosenoic (0.1) and arachidic (0.07) acids, SFA (17.67) and UFA ( } 81.21) \text {. }\end{array}$ & [21] \\
\hline Papaya seed & Oleic (47.7), linoleic (37.3) and palmitic (6.1) acids; UFA (87.5) & [22] \\
\hline Apricot & Palmitic (5.9), stearic (2.51) and behenic (0.66) acids; UFA (89.7) & [22] \\
\hline Soybean & Lauric (14.44), myristic (41.04), palmitic (3.46), stearic (1.5), oleic (14.54), linolenic (5.65) & [23] \\
\hline Coconut & Lauric (7.45), myristic (33.54)), palmitic (2.1), stearic (7.79), oleic (8.58), linolenic (9.2) & [23] \\
\hline Groundnut & Lauric (14.57), palmitic (4.75), stearic (12.07), oleic (12.72), linolenic (5.22) & [23] \\
\hline $\begin{array}{l}\text { Linoleic } \\
\text { sunflower oil }\end{array}$ & $\begin{array}{l}\text { Palmitic (6.18), stearic (3.98), oleic }(21.13) \text {, linoleic }(66.79) \text { linolenic }(<0.20) \text {, arachidic } \\
(0.20) \text {, behenic }(0.24) \text { and tetracosanoic acid }(0.24) ; \text { SFA }(11.27) \text { and UFA }(87.92)\end{array}$ & [24] \\
\hline Oleic sunflower & $\begin{array}{l}\text { Palmitic }(5.20) \text {, stearic }(3.36) \text {, oleic }(58.91) \text {, linoleic }(32.24) \text { linolenic }(0.20) \text {, } \\
\text { arachidic }(<0.20) \text {, behenic }(<0.20) \text { and tetracosanoic acid }(<0.20) \text {; SFA }(8.56) \text { and } \\
\text { UFA }(91.35)\end{array}$ & [24] \\
\hline Canola & $\begin{array}{l}\text { Palmitic (4.98), stearic (2.14), oleic (60.86), linoleic (22.42) linolenic (8.11), } \\
\text { arachidic }(0.88) \text {, myristic }(0.14) \text { and palmitoleic }(0.32) \text { acid }\end{array}$ & [25] \\
\hline
\end{tabular}




\subsection{Microbial Oils}

Oleaginous microorganisms are the microorganisms which contain lipid content over $20 \%$ of their dry weight and comprise some microalgae, yeasts, fungi (molds) and bacteria [26]. These microbial oils are the effective alternative sources of triglycerides and are similar to oleaginous seed lipids in the composition and hence are promisingly used for biodiesel production via the transesterification process $[13,26,27]$.

Lipid accumulation process occurs when nitrogen contents are limited and carbon in excess, starting at the end of the logarithmic growth phase until the depletion of carbon source, converting substrate into lipid reserves [12,27]. Microbial production of biodiesel occurs using either synthetic or complex media with sugars, oils, lignocellulosic biomass, etc. as carbon sources. Microorganisms are able to grow and accumulate oil in different types of substrates, presenting as advantage the ability to use wastes as feedstocks, such as waste oils, urban wastes and lignocellulosic biomass. Table 2 represents some microorganisms used in biodiesel production, divided into four groups: yeasts, fungi, microalgae and bacteria [26,28-34].

Table 2. Important microorganisms used in biodiesel production.

\begin{tabular}{llll}
\hline $\begin{array}{l}\text { Microorganism } \\
\text { (Group) }\end{array}$ & Specie & Substrate & Reference \\
\hline \multirow{2}{*}{ Yeast } & Rhodotorula graminis & Glucose & {$[26]$} \\
\cline { 2 - 4 } & Candida tropicalis and Yarrowia lipolytica & $\begin{array}{l}\text { Palm oil mill effluent and } \\
\text { crude glycerol }\end{array}$ & {$[28]$} \\
\hline \multirow{3}{*}{ Fungi } & Coniochaeta hoffmannii & Carrot pomace & [29] \\
\cline { 2 - 4 } & $\begin{array}{l}\text { lternaria alternata, Cladosporium } \\
\text { Cladosporioides, Epicoccum nigrum, } \\
\text { Fusarium oxysporum, Aspergillus parasiticus } \\
\text { and Emericella nidulans }\end{array}$ & Sugarcane molasses & [30] \\
\hline \multirow{2}{*}{ Bicroalgae } & Chlorella minutissima & Inorganic salts & [31] \\
\cline { 2 - 4 } & Scenedesmus obliquus and Desmodesmus spp. & Municipal wastewater & [32] \\
\hline & Serratia sp. & Municipal secondary sludge & [33] \\
\cline { 2 - 4 } & Bacillus sp. & Sewage sludge & [34] \\
\hline
\end{tabular}

\subsection{Urban Wastes}

Some urban wastes can also be used as biodiesel feedstock due to their high lipid contents or even as a substrate to grow oleaginous microorganisms. Waste palm oil generated after the cooking process was reported as having large amounts of fatty acids, composed mainly of oleic, palmitic and linoleic acid, i.e., with $42.39 \%, 36.63 \%$ and $9.85 \%$ of fatty acids respectively [35]. Apart from these, another urban waste used for biodiesel production is yellow grease, a waste from cooking that also contains a high percentage of free fatty acids. Gaurav et al. [15] demonstrated that canola oil was reported as having palmitic, oleic and linoleic acid. Sakdasri et al. [36] used waste palm oil from a restaurant and Giraçol et al. [37] studied cooking soybean oil residues from homes for biodiesel production. Moreover, other residues, such as municipal wastewater, can be utilized to grow oleaginous algae commonly used for biodiesel production [32]. In another study, Tran et al. [38] investigated grease trap waste for low-cost biodiesel production, as did Kech et al. [39] with wet urban sewage sludge. All the above-mentioned studies clearly indicated that a variety of urban wastes generated from different sources can be efficiently used as promising feedstocks for the production of biodiesel. Moreover, it is believed that the utilization of urban organic wastes for the production of biodiesel will also help to solve the problem of waste management as disposal of urban wastes is one of the major concerns for local municipal corporations. 


\section{Conventional Methods Used for Biodiesel Production}

Several methods have been investigated in the few last decades for biodiesel production as a substitution of fossil fuels. However, some methods present critical problems due to high viscosity, low volatility and polyunsaturated properties of employed oils [40]. Other products such as aldehydes, ketones, polymers, shorter chain fatty acids and others may be produced during esterification due to the oxidation of fatty compounds [41]. The presence of these compounds may negatively affect biodiesel quality, which may become a major problem considering fuel injection and combustion [42]. This allows the development of techniques that permits the utilization of several lipidic feedstocks, such as natural oils [20,21,43], urban oils [44], or even some oils produced by microorganisms [20,28]. The implication of different techniques such as transesterification is presented as the conventional methodology for the production of industrial biodiesel and can be performed by employing homogeneous or heterogeneous catalysis methods [45], which present unique advantages and disadvantages as shown below.

\subsection{Catalyst-Assisted Methods}

Transesterification is considered the best route for the utilization of oils in substitution to fossil diesel, once it generates the biodiesel with similar viscosity and cetane index [46]. The catalyst-assisted approaches are the most traditional proposals for the production of biodiesel and can be performed using homogeneous or heterogeneous methods (Figure 2). Homogeneous catalysis is presented as a simple, fast and high-yielding process, with a strong catalytic agent with fewer disadvantages or limitations [47]. Heterogeneous catalysis is presented as an interesting approach as far as biodiesel production is concerned because this approach is more selective and eco-friendly [44].

The transesterification of different oils can be performed by adding alcohol, generally methanol or ethanol for the production of esters and glycerin [40]. Generally, a catalyst is added to the reaction, promoting a three-step cascade breakdown of triglyceride in diglyceride and finally to monoglyceride in the last step. From the produced monoglyceride, glycerin is obtained. Several relevant variables are described in the literature such as different alcohol, catalysts, reaction temperature, mixing intensity, as well as the alcohol to catalyst ratio for the effective utilization of oils [44]. The most employed catalysts applied to biodiesel production are alkali, acid and enzymatic. Figure 2 shows traditional approaches for the production of biodiesel from oils.

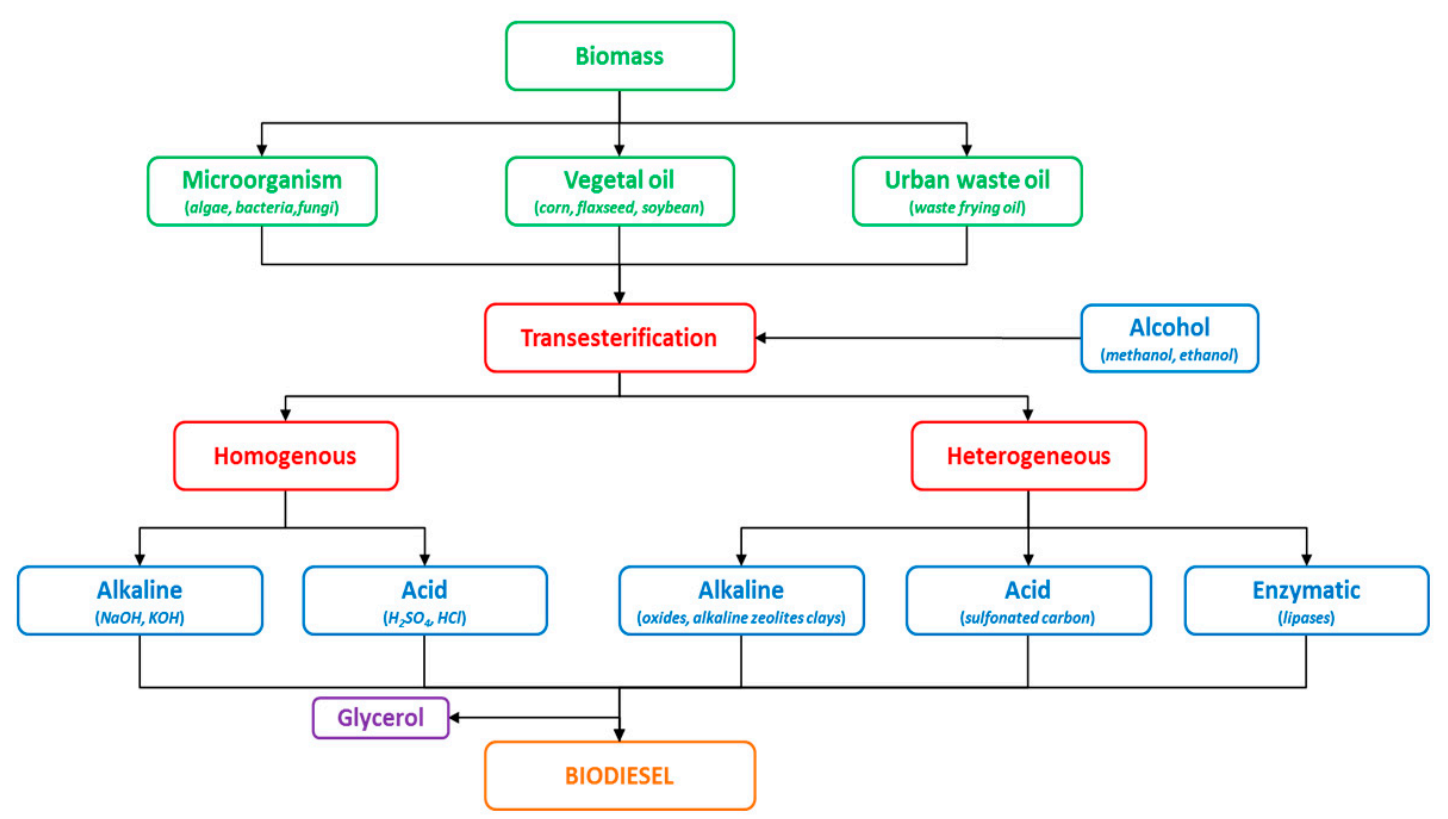

Figure 2. Traditional approaches for the production of biodiesel from oils. 


\subsubsection{Alkaline-Catalyzed Methods}

Homogeneous base-catalyzed reactions are inexpensive due to the availability of reagents such as $\mathrm{NaOH}$ and $\mathrm{KOH}$, which are currently the most employed alkali catalysts. The application of these catalysts can be performed in all kinds of oils, such as refined, crude or frying oils [44,48]. The transesterification reactions are performed in mild temperature and pressure conditions and required short reaction time [44]. The limitation of this technology is based on process sensitivity to the reactants purity, the employed fatty acids and the water concentration presented in the sample. Too much water may result in the hydrolysis of triglycerides in diglycerides and FFA (free fatty acids), so water use must be controlled in this process in order to obtain high-quality biodiesel. The resence of FFA in large concentrations may lead to saponification and consequently, soap production instead of biodiesel production, promoting an emulsion formation and increasing the downstream recovery, increasing the purification processes cost and generating large amounts of contaminated liquid effluent $[42,44]$.

The development of new green heterogeneous catalysts has been increased in the latest years, as they are easy to reuse, does not present corrosion problems and presents longer lifespans [40]. The utilization of heterogeneous based-catalysts is usually employed in high-purity feedstocks and low water and FFA content [44]. Recent studies showed effective utilization of heterogeneous based-catalysts composed by the utilization of several metal oxides, alkaline zeolites and some clays [41,49-51]. These processes may be employed alone or a combination with some other approaches [43]. However, the major drawbacks of the heterogeneous based-catalysts are the presence of low levels of FFA, high molar alcohol and oil proportion, diffusion limitation, high cost when compared with traditional reactions and catalyst leaching stills makes the commercialization of heterogeneous catalysts as a major challenge [40,44].

\subsubsection{Acid-Catalyzed Methods}

Hydrochloric acid $(\mathrm{HCl})$ and sulphuric acid $\left(\mathrm{H}_{2} \mathrm{SO}_{4}\right)$ are the most commonly employed catalysts for acid-catalyzed transesterification. A homogeneous acid catalyst presents some advantages when compared with alkali-catalyzed methods, e.g., it can catalyze esterification and transesterification simultaneously and it is not sensitive to the presence of FFA, allowing its employment on low-cost feedstocks such as waste frying oils in order to reduce the acidity of a medium [44,47]. The present disadvantages of this method are the necessity of more severe conditions, such as temperature, reaction time and oil to alcohol ratio, when compared to the alkaline method. Other typically associated problems are product recovery after neutralization and residue generation [44].

Heterogeneous acid catalysis is majorly executed by the utilization of inorganic polymeric materials such as heteropoly acid and sulfonated carbons, which promotes a sustainable technology as it presents an easy separation from the reaction medium, reusability and does not cause the equipment corrosion as the homogeneous acid catalyst [44,48]. The metal-organic frameworks (MOFs) and covalent-organic frameworks (COFs) are also cited as presenting advantages when compared to other catalysts, such as larger surface area and regular pore, resulting in a high capacity for storing ions [52]. The highly cross-linked amorphous covalent-organic polymers (COPs) such as the mesoporous melamine-formaldehyde polymer (MMFP) are considered an outstanding chemical by its hydrothermal stabilities, also presenting the characteristics presented on MOFs and COFs. The utilization is limited at some crucial points for utilizing the HPA as low surface area, high solubility, low thermal stability and difficulties in fabrication of chemically antagonistic functions [52] and low contents of acid sites are related to the nanoporous inorganic-oxides regularly presenting low catalytic activity. 


\subsection{Lipase-Catalysed Methods}

Lipases are heterogeneous biochemical catalyzers majorly produced by microorganisms and used for the production of biodiesel and glycerol. They can be used as the catalyst for transesterification and esterification reactions and present a great industrial interest once it can be employed as an effective catalyst for lipidic feedstocks, acting in mild temperature and pressure conditions at present high reactional yields [53]. The biocompatibility and biodegradability of the lipases make it as the most environmentally accepted method, promoting its utilization for agricultural and medical applications [45].

Several microorganisms have been reported in the literature as the efficient producers of lipase which commonly used in biodiesel production. Candida antarctica is reported as the most important yeast as far as production of lipase B is concerned, however, apart from this, some other Candida species are reported as good producers of lipases [53]. Some of the studies performed also demonstrated that the possibility of production of lipases from filamentous fungi like Rhizomucor, Thermomyces, Aspergillus and Penicillium [54]. Similarly, bacterial species like Proteus and some Streptomyces also reported to produce lipases and the produced lipases were efficiently used for the biodiesel production [53].

In addition, recombinant heterologous lipases have been developed which showed improved thermostability and tolerance towards denaturation from methanol. As lipases naturally occur in free from, several support materials have been developed for the immobilization of these enzymes, such as alginate, chitosan and silica gel [55]. Several techniques such as physical adsorption, ionic bonding or covalent bonding, entrapment cross-linking techniques, etc. can be promisingly used for immobilization of lipases [56]. Whole-cells have also been studied as a new method for the production of biodiesel and present some advantages such as simplified operation process and production costs reduction [57].

Solid enzymatic preparation (SEP) is another technique which is associated with solid state fermentation (SSF), where the fungal cells can grow naturally in immobilization structures to secretes the lipases which will be used as biocatalysts [58]. The disadvantages associated with enzyme-catalyzed transesterification are mainly related to production of lipases such as enzyme robustness, low yields, purification and stability [53]. In addition, the high production cost of enzyme and longer enzymatic reaction time are some other limitations of enzyme-catalyzed transesterification when compared to the alkali catalysis transesterification [58].

\section{Nanocatalysts in Biodiesel Production}

As discussed earlier, biodiesel (fatty acid methyl esters) usually prepared through the transesterification oils derived from animal, plant, or oleaginous microorganisms after their reaction with alcohol like methanol [59]. However, this technology has some major problems which mainly include saponification, deactivation of the catalyst and low reaction rate [60]. Therefore, in order to overcome these challenges scientists believed that nanotechnology can be effectively used. Over the period of last few years, nanotechnology has emerged as the most promising technology having revolutionary applications in numerous fields. It is commonly defined as synthesis, manufacturing and applications of the matters with atomic or molecular precision at dimensions in the size range of 1-100 nm [61]. Nanomaterials are considered to be the building blocks of nanotechnology that possess several novel and unique properties. Nanomaterials like metal nanoparticles reported to have the surface area several hundred times more than their equal weight of macroscale materials. Besides the extensive increase in surface area, other properties like tenacity, elasticity, catalytic activity, electricity, strength, etc. were also found to be enhanced at the nanoscale [59]. Recent advances in the field of nanotechnology and some of the noteworthy studies performed proposed that among all the above-mentioned properties, the potential catalytic efficacy of nanomaterials makes them the most popular catalysts in biofuel production, and particularly in biodiesel production.

To date various nano-based normal or functionalized heterogeneous catalysts having promising catalytic properties such as high activity, surface reactivity, large pore size, large surface area, etc. have 
been synthesized and utilized for the production of biodiesel [62]. Kumar et al. [63] proposed that a typical heterogeneous catalyst usually consists of few nanoparticles dispersed on highly porous material having surface area up to $250 \mathrm{~m}^{2} / \mathrm{g}$. Some of the important solid nanocatalysts which have been used in biodiesel production are metal oxides (Cao, $\mathrm{MgO}, \mathrm{Fe}_{3} \mathrm{O}_{4}, \mathrm{Ca} / \mathrm{Al} / \mathrm{Fe}_{3} \mathrm{O}_{4}, \mathrm{KF} / \mathrm{Al}_{2} \mathrm{O}_{3}, \mathrm{SnO}_{2}$, etc.), sulfated oxides, hydrotalcites, zeolites, zirconia, etc. [64,65]. Among these, some of nanocatalysts have been briefly discussed below. Figure 3 shows the important nanocatalysts commonly used in biodiesel production.

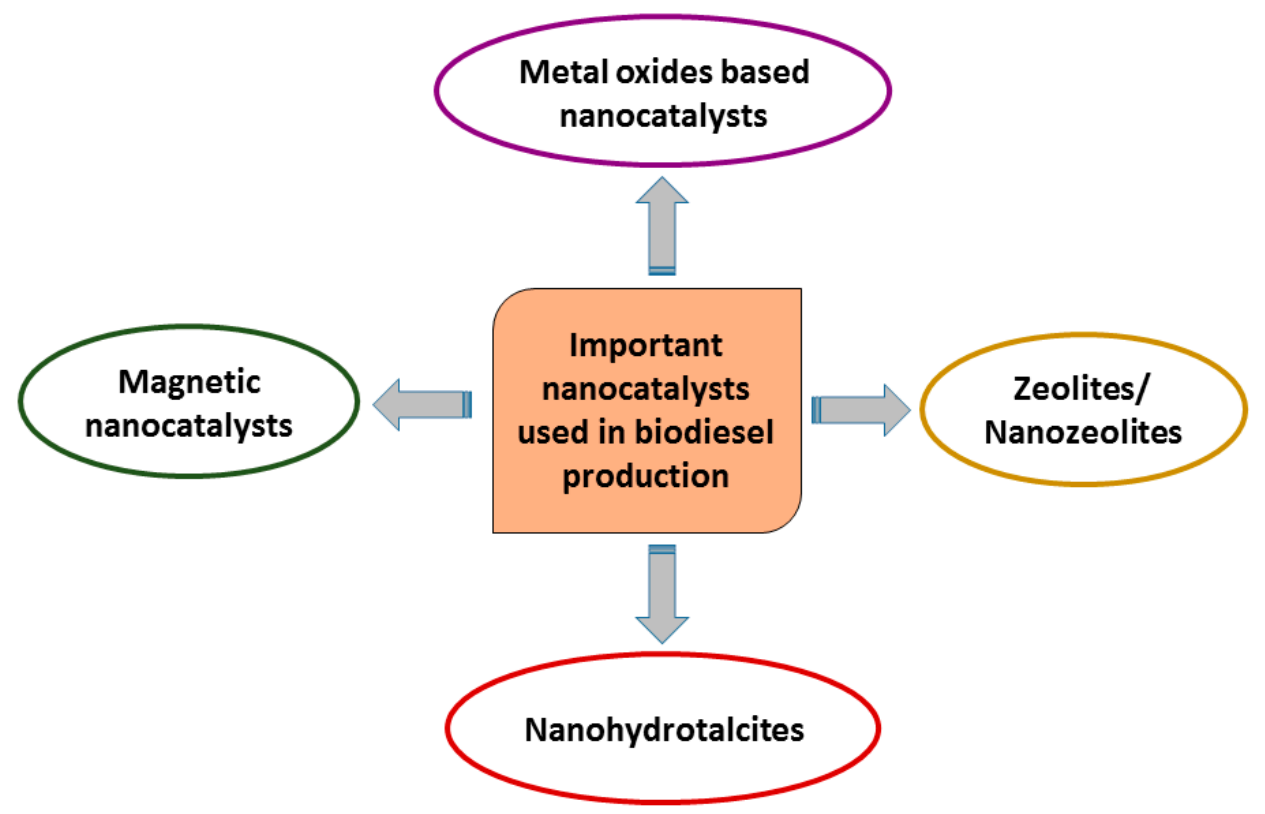

Figure 3. The important nanocatalysts commonly used in biodiesel production.

\subsection{Metal Oxide-Based Nanocatalysts}

Among different heterogeneous nanocatalysts, metal oxide-based nanocatalysts are considered as most promising and hence widely studied in production of biodiesel from a variety of feedstocks.

Faria et al. [66] synthesized nanosized $\mathrm{SiO}_{2} / \mathrm{ZrO}_{2}$ catalyst by the sol-gel method having high surface area. Further, this catalyst was evaluated for its efficacy in the transesterification of soybean oil for biodiesel production. It was reported that this catalyst exhibit promising catalytic activity showing about $96.2 \pm 1.4 \%$ biodiesel conversion yield after $3 \mathrm{~h}$ of reaction. Moreover, it was also observed that after recovery, this catalyst can be reused for six more cycles of transesterification with little drop in catalytic efficiency (biodiesel conversion yield $=84.1 \%$ ). Qiu et al. [67] synthesized $\mathrm{C}_{4} \mathrm{H}_{4} \mathrm{O}_{6} \mathrm{HK}$ (potassium bitartrate)-loaded $\mathrm{ZrO}_{2}$ nanocatalyst with size ranges from 10 to $40 \mathrm{~nm}$, and investigated its use in the production of biodiesel via the transesterification of soybean oil and methanol in different molar ratios. Moreover, various other reaction parameters like reaction temperature, nanocatalyst concentration, and reaction time were also optimized. The results obtained revealed that the maximum biodiesel yield of about $98.03 \%$ can be achieved at methanol and oil molar ratio of $16: 1$ having $6.0 \%$ nanocatalyst at $60^{\circ} \mathrm{C}$ for $2 \mathrm{~h}$.

Madhuvilakku and Piraman [68] successfully synthesized s $\mathrm{TiO}_{2}-\mathrm{ZnO}$ nanocatalyst and employed in transesterification of Palm oil to produce FAME. Formation of defects on the catalyst surface due to the substitution of $\mathrm{Ti}$ on the $\mathrm{Zn}$ lattice improves catalytic activity and stability. They reported $98 \%$ oil conversion, and a $92 \%$ biodiesel yield was obtained under the reaction conditions of $200 \mathrm{mg}$ catalyst, a methanol to oil molar ratio of $6: 1,60{ }^{\circ} \mathrm{C}$ temperature and $5 \mathrm{~h}$ time. Other studies performed demonstrated the synthesis of sulfated doped $\mathrm{TiO}_{2}$ solid acid nanocatalyst which can be promisingly used in a petroleum refinery in various process. According to the authors, these catalysts showed better performance compared to other sulfated metal oxides and this is mainly due to the acid strength 
of the $\mathrm{TiO}_{2}$ particles which can be increased by loading of the $\mathrm{SO}_{4}{ }^{2-}$ groups on the surface of $\mathrm{TiO}_{2}$. These catalysts showed promising efficacy in the synthesis of biodiesel from cooking oil $[69,70]$. Similarly, bimetallic catalysts supported on metal oxides i.e., $\mathrm{Cu}-\mathrm{Ni}$ supported on $\mathrm{TiO}_{2}, \mathrm{ZrO}_{2}, \mathrm{CeO}_{2}$, etc. were also found to be most effective in catalysis of reaction responsible for biofuel like biodiesel production [71,72]. Baskar et al. [73] reported on Mn doped $\mathrm{ZnO}$ nanomaterial for the transesterification of Mahua oil and found that the catalyst calcined at $600{ }^{\circ} \mathrm{C}$ shows maximum biodiesel yield of $97 \%$ under the optimized reaction conditions such as $8 \mathrm{wt} . \%$ catalyst loading, 7:1 methanol to oil ratio, $50 \mathrm{~min}$ time and $50^{\circ} \mathrm{C}$ temperature. The kinetic study of the reaction shows that $181.91 \mathrm{~kJ} / \mathrm{mol}$ activation energy is required for transesterification of Mahua oil using Mn doped $\mathrm{ZnO}$ catalyst.

In another study, acid-functionalized magnetic nanoparticles were synthesized and used as heterogeneous nanocatalysts for the production of biodiesel. In this study, sulfamic and sulfonic acid functionalized silica-coated crystalline $\mathrm{Fe} / \mathrm{Fe}_{3} \mathrm{O}_{4}$ core/shell, magnetic nanoparticles were used in transesterification of glyceryl trioleate. The results obtained show that both acid-functionalized (sulfamic and sulfonic acid) nanocatalysts found to have a promising catalytic performance. However, the sulfamic acid-functionalized nanocatalysts showed considerably enhanced activity compared to sulfonic acid-functionalized nanocatalysts [74]. Alves et al. [75] demonstrated the feasibility of application of mixture of iron/cadmium (Fe/Cd) and iron/tin (Fe/Sn) oxide nanoparticles having magnetic properties for the production of biodiesel from soybean oil as a rapid and easy nanotechnological approach. Among these two nanocatalysts, Fe/Sn oxide nanoparticles showed maximum catalytic performance with a biodiesel yield of $84 \%$. Further, authors suggested that such nanocatalysts exhibits significant potential toward hydrolysis, transesterification, and esterification of soybean oil and their fatty acids.

Similarly, CaO-based nanocatalysts are also found to be efficient catalysts for the transesterification process of different oil feed stocks for the production of biodiesel [76]. According to Kumar et al. [63] there are four forms of $\mathrm{CaO}$ nanocatalysts like neat $\mathrm{CaO}$, doped $\mathrm{CaO}$, loaded $\mathrm{Cao}$ and waste $\mathrm{CaO}$, all these are commonly used as effective nanocatalysts in synthesis of biodiesel form different oil feed stocks. However, loaded $\mathrm{CaO}$ and doped $\mathrm{CaO}$ based catalysts are mostly preferred than neat $\mathrm{CaO}$ because these rapidly form hydrogen bond with methanol and glycerol. Reddy et al. [77] attempted to use neat $\mathrm{CaO}$ nanocatalysts for the production of biodiesel from poultry fat with alcohol:oil molar ratio of 10:3 at room temperature and it was found that this used a CaO-based nanocatalyst showing $100 \%$ yield conversion at this reaction condition. Similarly, another study involving the use of same nanocatalyst with palm oil as feedstock and alcohol:oil molar ratio of $15: 1$ at $60{ }^{\circ} \mathrm{C}$ showed $95.7 \%$ yield conversion [78]. Moreover, in case doped of supported $\mathrm{CaO}$, Wen et al. [79] synthesized $\mathrm{KF} / \mathrm{CaO}$ nanocatalyst by impregnation method having with size range in between $30-100 \mathrm{~nm}$ and evaluated their activity towards production of biodiesel from Chinese tallow seed oil. This study reported about $96.8 \%$ of biodiesel yield showing potential of such nanocatalyst for the biodiesel industry. In another similar study, Hu et al. [80] demonstrated the production of biodiesel using microporous solid base $\mathrm{KF} / \mathrm{CaO}$ as nanocatalyst from rapeseed oil with alcohol:oil molar ratio of 6:1-12:1 at 70-90 ${ }^{\circ} \mathrm{C}$. The results recorded showed about $93 \%$ yield conversion. In another similar study, graphite oxide-supported $\mathrm{CaO}$ nanocatalysts were used to achieve higher yield of biodiesel. It was reported these catalysts showed about $99 \%$ conversion rate with $15: 1$ alcohol:oil molar ratio at $70{ }^{\circ} \mathrm{C}$ from jatropha oil and about $97.8 \%$ yield from soybean oil with 15:1 alcohol:oil molar ratio at $60^{\circ} \mathrm{C}$ [81]. Apart from these, Tahvildari et al. [82] investigated the production of biodiesel from cooking oils, using $\mathrm{CaO}$ and $\mathrm{MgO}$ nanoparticles synthesized by sol-gel and sol-gel self-combustion methods, respectively. $\mathrm{CaO}$ nanoparticles showed significant increase in the biodiesel yield compared to $\mathrm{MgO}$ nanoparticles. The above-mentioned reports discussed are enough to drawn a conclusion that various metal oxide based nanocatalysts one of the most efficient heterogeneous catalysts as far as biodiesel production from different feedstocks is concerned. 


\subsection{Nanohydrotalcites}

Hydrotalcites are the another kind of materials which are quite prevalent in nature and these are gaining growing interested day by day because of their very wide range of potential applications and uses. However, it is also possible to prepare hydrotalcite and in for this co-precipitation methods are the most preferably used [83]. Considering the wide spread utility of hydrotalcite, recently researchers are focusing on development of nanohydrotalcites which are commonly known as anionic clays or aluminum-magnesium layered double hydroxides. The hydrotalcite compounds are among the class of two-dimensional nanostructured anionic clays that contains two types of metallic cations accommodated with the aid of a close packed configuration of $\mathrm{OH}$ groups in a positively charged brucite-like layer $[83,84]$.

Some of the studied performed in recent past demonstrated that nanohydrotalcites can be effectively used in the production of biodiesel. Deng et al. [85] developed hydrotalcite-derived nanoparticles with $\mathrm{Mg} / \mathrm{Al}$ oxides by a co-precipitation method using urea as precipitating agent and further evaluated their catalytic efficacy for transesterification of Jatropha oil. The author claimed that the used nanocatalysts were promising and showed $95.2 \%$ yield of biodiesel. In another study, Dias et al. [86] synthesized cerium modified Mg-Al hydrotalcites and further it was used as catalysts in the methanolysis of soybean oil for the production of FAMEs, the results obtained showed that FAMEs yields higher than $90 \%$ can be obtained using such catalyst. Another report also demonstrated the synthesis of $\mathrm{Mg}$-Al nanohydrotalcite and for the first time used them as a catalyst for transesterification of Pongamia oil, a maximum biodiesel conversion of about $90.8 \%$ was achieved at $6: 1$ molar ratio of methanol and catalyst, $65^{\circ} \mathrm{C}$ temperature [87]. It was proposed that nanoengineered macroporous hydrotalcites potentially enhanced the catalytic production of biodiesel. The macroporous $\mathrm{Mg}-\mathrm{Al}$ hydrotalcites synthesized through alkali-free co-precipitation showed higher catalytic performance in the transesterification of $\mathrm{C}_{4}-\mathrm{C}_{18}$ triglycerides. Moreover, it was claimed that the high catalytic performance of $\mathrm{Mg}$ - $\mathrm{Al}$ hydrotalcites was mainly because of diffusion of bulky triglycerides due to porous nature of catalyst and easy accessibility of active sites present on the developed catalyst [88].

Similarly, Manivannan and Karthikeyan [89] developed Mg-Al nanohydrotalcites and used as solid base catalysts in a heterogeneous manner for the methanolysis of neem oil to obtain methyl esters. Further, they also studied effect of the various reaction parameters like temperature, time, catalyst amount, and methanol/oil molar ratio on the efficacy of $\mathrm{Mg}$-Al nanohydrotalcite. The observations recorded suggested that the reaction temperature play important role in the resulting yield of biodiesel. It was found that at room temperature the yield of FAME is low and it increases with increases in temperature at particular temperature. The maximum yield of $84 \%$ was reported at reaction temperature of $65^{\circ} \mathrm{C}$; however, further increase in temperature decline the yield of FAME.

Gao et al. [90] prepared different $\mathrm{KF} / \mathrm{Ca}-\mathrm{Mg}$-Al hydrotalcite with different cation ratios. Further, they evaluated effects of different cation ratio of the $\mathrm{Ca}-\mathrm{Mg}$-Al hydrotalcite and the methanol/oil molar ratios on the yield of FAME through the transesterification of palm oil. The results obtained suggested that all these hydrotalcite showed considerably high catalytic efficacy in the transesterification reactions to obtain biodiesel. About $90 \%$ yield of FAME was obtained within 10 min of reaction with 12:1 methanol/oil molar ratio, and 5\% (wt/wt oil) catalyst amount at $338 \mathrm{~K}$. Moreover, it also observed that even higher yield of FAME (99.6\%) can be achieved in $10 \mathrm{~min}$ using $\mathrm{KF} / \mathrm{Ca}-\mathrm{Mg}$-Al hydrotalcite with specific amount of each content of this catalyst (i.e., 2.2:0.8:1 Ca/Mg/Al; KF mass ratio of $100 \%$ ). According to Chelladurai and Rajamanickam [84] application of nanohydrotalcite for the production of biodiesel is environment friendly because the process can be carried out at ambient temperature. In this context, authors proposed the use of nano- $\mathrm{Zn}-\mathrm{Mg}$-Al hydrotalcite as solid base catalysts for the production of biodiesel from neem oil through transesterification. It was reported that the catalytic performance of the used nano- $\mathrm{Zn}-\mathrm{Mg}$-Al hydrotalcite is significantly increased due to incorporation of $\mathrm{Zn}$ into the surface of $\mathrm{Mg}$ - $\mathrm{Al}$ hydrotalcite material. A maximum FAME conversion of $90.5 \%$ was recorded for 10: 1 methanol: oil molar ratio and $7.5 \mathrm{~g}$ at $65^{\circ} \mathrm{C}, 450 \mathrm{rpm}$ for $4 \mathrm{~h}$ reaction and with the catalysts ratio of $\mathrm{Zn}-\mathrm{Mg}-\mathrm{Al}$ as 3:3:1. Recently, Prabu et al. [91] also found that the modification 
of Mg-Al nanohydrotalcite can enhance its catalytic performance. Therefore, authors developed $\mathrm{Mg} / \mathrm{Al} / \mathrm{Zn}$-based hydrotalcite/SBA-15 composite material and investigated their catalytic activity for the transesterification of vegetable oil (soybean oil) in the presence of methanol. It was reported that the incorporation of $\mathrm{Zn}$ in $\mathrm{Mg} / \mathrm{Al}$ hydrotalcite greatly influences the textural characteristics, density of the basic sites, and the catalytic activity of this nanohydrotalcite composite. Moreover, $\mathrm{Mg} / \mathrm{Al} / \mathrm{Zn}$-based hydrotalcite/SBA-15 reported to have high catalytic performance which was proved from high yield of biodiesel $(90 \%)$ achieved at ambient reaction conditions.

Above mentioned reports presented that application of $\mathrm{Mg} / \mathrm{Al}$ catalysts at different molar ratios (i.e., within the range of 1.5-5) can be promisingly used in biodiesel production. It was also found that high ratios of $\mathrm{Mg} / \mathrm{Al}$ catalyst showed excellent characteristics despite a low surface area [92]. However, Di Serio et al. [93] claimed that calcined Li/Al hydrotalcites were most active in the glycerolysis of fatty acid than $\mathrm{Mg} / \mathrm{Al}$ material due to high Lewis basicity. Similarly, Gutiérrez-Ortega et al. [94] reviewed the role of $\mathrm{Co} / \mathrm{Fe}$-mixed oxides as heterogeneous catalysts in the production of biodiesel. In this article, authors mentioned that all the different kinds of nanohydrotalcite including $\mathrm{Co} / \mathrm{Fe}$-mixed oxides can be effectively used for transesterification of various oils. Therefore, from all the studies discussed herewith, it can be concluded that the application of different nanohydrotalcites in biodiesel production will be novel ecofriendly alternative.

\subsection{Zeolites/Nanozeolites}

Zeolites are another kind of catalysts which are also used in industrial production of biodiesel. These are known for their promising catalytic performance due to the presence of strong acid sites, high surface area, shape selectivity, and unique molecular sieving properties hence being used for a variety of catalytic application since many decades [95]. Considering the wide range of catalytic applications of zeolites including biodiesel production, currently scientific community focusing on devolvement and utilization of nanozeolites for even better efficacy. Nanozeolites are hydrophobic supports having high external surface areas, and their high dispersibility in both aqueous solutions and organic media allows better access of the enzymes to the substrate. Moreover, as discussed earlier enzyme-catalyzed processes involving the use of lipases enzymes were found to be effective in transesterification of triacylglycerides. Considering these facts, researchers have developed nanozeolites-enzyme complexes as a most promising catalysts for the enhanced production of biodiesel. It is proved that application of nanozeolites as solid support for the immobilization of catalytic enzymes like lipases increases the catalytic of activity of immobilized enzyme compared to free enzyme. It is believed that the increase in the catalytic activity of immobilized enzymes was mainly due to their enhanced stability towards higher temperature and other environmental conditions. Apart from these, the most important advantage in the application of such nanozeolite-enzyme complexes is their reusability. Due to the immobilization of catalytic enzymes on solid nanosupports it is possible to recover them and reuse them in consecutive cycles of transesterification of triacylglycerides $[8,96]$.

In this context, de Vasconcellos et al. [8] studied the possibility of nanozeolites with various crystallographic structures functionalized with (3-aminopropyl) trimethoxysilane (APTMS) and cross-linked with glutaraldehyde as solid supports for immobilization of lipase recovered from Thermomyces lanuginosus. Further, authors also demonstrated the role of the developed enzyme-nanozeolite complexes in ethanolysis transesterification of microalgae oil to FAEEs. The results obtained in this study revealed that the used nanozeolites functionalized with APTMS and cross-linked with glutaraldehyde showed ability to immobilize higher amounts of enzymes and these enzyme-nanozeolite complexes also reported to exert comparatively higher enzymatic activities than free enzyme (non-functionalized). The FAEEs yield above $93 \%$ was recorded using these lipase-nanozeolite complex. After first reaction, the catalyst was recovered as reused for next five consecutive cycles of ethanolysis transesterification and most interestingly same yield was obtained even after five cycles, this indicated the stability of immobilized enzyme. Moreover, it was reported immobilization of enzyme through covalent bonding found to be more promising compared to physical 
adsorption, in case of enzyme-nanozeolite complex prepared using These observations indicated that development of highly efficient biocatalysts for the production biodiesel is possible via chemical modulation of nanozeolite surfaces.

In another study, Al-Ani et al. [95] developed nanostructured zeolites as intracrystalline mesoporous basic Faujasite-type catalysts. In this study, authors have synthesized basic cation-rich hierarchical zeolites $X$ and $Y$ through a combination of post-synthesis modifications and ion exchange and further evaluated their efficacy in biodiesel production from vegetable oils. The results obtained showed promising catalytic performance of the prepared cation-rich hierarchical zeolites which was indicated from increased conversion of triglycerides through tranesterification process of vegetable oils. Similarly, in their recent study, Al-Ani et al. [97] developed another type zeolite based nanostructured catalyst, i.e., ion-exchanged zeolite $\mathrm{P}$ for the production of biodiesel and here also authors reported better catalytic performance of the used nano-sized zeolite.

Saeedi et al. [98] prepared zeolite imidazolate framework (ZIF-8) doped with potassium $(\mathrm{KNa} / \mathrm{ZIF}-8)$ and these catalysts were used in the production of biodiesel from soybean oil as the feedstock via transesterification process. Further, to increase the basicity and to enhance the catalytic performance of ZIF-8 during transesterification with methanol, sodium and potassium were added to it. A remarkable conversion of $>98$ was recorded in case of KNa/ZIF- 8 at methanol/oil molar ratio of 10:1 and $3.5 \mathrm{~h}$ of reaction time. Moreover, this solid catalyst was recycled for about three times and reused. Recently, Amalia et al. [99] demonstrated the production of biodiesel from Castor (Ricinus communis) oil was using heterogeneous $\mathrm{KOH} /$ zeolite catalyst through the process of transesterification. After optimization of different reaction parameters and condition, promising transesterification was observed at $55^{\circ} \mathrm{C}, 7 \mathrm{~h}$ reaction time and $70 \%$ catalyst concentration.

Since last few years, production of biodiesel from used vegetable oil is attracted a great deal of attention because it involves the use of waste edible oil and their recycling which as considered as one of the major social problem worldwide. In this context, Brito et al. [100] demonstrated the efficacy of zeolite $\mathrm{Y}$ with different $\mathrm{Al}_{2} \mathrm{O}_{3}$ content as catalyst for the methanolysis transesterification of waste oil. It was observed that these catalysts showed promising catalytic efficacy in between 466 and $476{ }^{\circ} \mathrm{C}$, 12.35 and 21.99 min reaction time, and a methanol/oil molar ratio of 6 . Similarly, in another study, zeolite-based catalyst was prepared from a fine powder and kaolinite by pelletization process. Further, it was used to produce FAMEs which are noting but the biodiesel from waste cooking oil containing high amounts of free fatty acids. The data obtained indicated that the synthesized zeolite-based catalyst has ability to simultaneously catalyze two different processes, i.e., the esterification of fatty acids and transesterification of triglycerides. The maximum conversion of triglyceride (46\%) was achieved at $50-85{ }^{\circ} \mathrm{C}$ reaction temperature, $2.6-6.0$ methanol/waste cooking oil molar ratio and $2-10 \mathrm{~h}$ of reaction time [101]. Apart from various other attempts were made for the use of different zeolites and nanozeolites in the production of biodiesel and hence related reports are also reviewed in some review articles published in last few years. Overall, all these studies confirmed that zeolites and nanozeolites can be effectively used as heterogeneous catalysts for enhanced catalytic performance.

\subsection{Magnetic Nanocatalysts}

Like solid supported nanocatalyst, nowadays, magnetic nanocatalysts have attracted a great of attention from researchers. Because of outstanding magnetic properties, magnetic nanocatalysts can be reused more than one cycle of transesterification. Various attempts have been made in this direction and a variety of magnetic nanocatalysts were developed and employed in the transesterification of different feedstocks for the production of biodiesel. The easy recovery and reuse of same nanocatalysts provide the economic viability to the process. In this context, Hu et al. [102] have developed novel magnetic nanocatalyst i.e., $\mathrm{KF} / \mathrm{CaO}-\mathrm{Fe}_{3} \mathrm{O}_{4}$ having porous structure and used as for synthesis of biodiesel from Stillingia oil. Thus, synthesized magnetic nanocatalyst reported to have particle diameter of about $50 \mathrm{~nm}$. The Brunauer-Emmett-Teller surface area was $20.08 \mathrm{~m}^{2} / \mathrm{g}$ compared to only $4.6 \mathrm{~m}^{2} / \mathrm{g}$ for $\mathrm{CaO}$. The results obtained showed about $95 \%$ yield FAMEs at optimal conditions like temperature at 
$65{ }^{\circ} \mathrm{C}$, a methanol/oil molar ratio of $12: 1$ and a catalyst concentration of $4 \mathrm{wt} . \%$ after $3 \mathrm{~h}$ of reaction. Moreover, it was also observed that same magnetic nanocatalysts can be reused up to 14 times without much loss in its activity and it is possible to recover more than $90 \%$ of catalyst when used at above mentioned condition.

Alves et al. [75] developed a rapid, simple, economically viable nanotechnological approach for the production of biodiesel from soybean oil. Here, authors synthesized a mixture of iron/cadmium and iron/tin oxide nanoparticles with magnetic properties by co-precipitation method and the synthesized nanocatalysts were evaluated for their efficacy in hydrolysis and transesterification of soybean oil as well as esterification of soybean oil fatty acids. In the esterification assisted by iron/tin oxide nanoparticles high yields, ca. $84 \%$, was recorded, at $200^{\circ} \mathrm{C}$ and $1 \mathrm{~h}$ of reaction time. Further, these nanocatalysts were magnetically recovered and reused about four times without loss in its activity, however, a loss of activity was observed for iron/cadmium oxide nanoparticles catalyst. In another study, Feyzi and Norouzi [103] reported synthesis of a $\mathrm{Ca} / \mathrm{Fe}_{3} \mathrm{O}_{4} @ \mathrm{SiO}_{2}$ nanocatalyst using combination of two different approaches, i.e., sol-gel and incipient wetness impregnation method. Thus synthesized nanocatalysts reported to have strong magnetic properties, further, this magnetic nanocatalyst was used in the production of biodiesel. The data obtained revealed that the used magnetic nanocatalysts showed very effective catalytic activity at optimum conditions which was indicated from maximum yield of biodiesel (about 97\%). The magnetic nature of nanocatalyst supported its reuse for several times without significant loss in its catalytic activity. In a similar approach, Alaei et al. [104] synthesized magnetic and reusable $\mathrm{MgO} / \mathrm{MgFe}_{2} \mathrm{O}_{4}$ nanocatalyst for biodiesel production from sunflower oil. Here, considerably high conversion of about $91.2 \%$ was reported using this catalyst at optimum conditions such temperature of $110^{\circ} \mathrm{C}$, methanol-to-oil molar ratio of 12 , catalyst concentration of $4 \mathrm{wt} . \%$ and reaction time of $4 \mathrm{~h}$. This indicated the promising catalytic potential of the used magnetic catalysts towards production of biodiesel. However, after recovery same nanocatalyst was reused for next five consecutive transesterification reactions that the results were very acceptable and finally the lowest conversion recorded was about $82.4 \%$.

Recently, Salimi and Hosseini [105] reported the synthesis of $\mathrm{ZnO} / \mathrm{BiFeO}_{3}$ magnetic nanocatalyst by co-precipitation method and demonstrated their use for the biodiesel production from canola oil through a transesterification reaction. Authors, claimed that application such cheap and novel magnetic nanocatalyst could be helpful in its easy separation from the reaction products by applying magnetic field. A promising catalytic efficacy was reported for this catalyst which was indicated from the high yield of biodiesel, i.e., 95.43 and $95.02 \%$ in first and second cycle, respectively at optimum conditions such as molar ratio of methanol/canola oil of $15: 1$, a reaction temperature of $65^{\circ} \mathrm{C}$ and a catalyst amount of $4 \mathrm{wt} \%$, The catalyst was reported to reused for about five times and, the FAME yield maintained more than $92.08 \%$ after five times. Similarly, another recent report by Ghalandari et al. [106] demonstrated the synthesis of a magnetic core-mesoporous shell $\mathrm{KOH} / \mathrm{Fe}_{3} \mathrm{O}_{4} @ \gamma-\mathrm{Al}_{2} \mathrm{O}_{3}$ nanocatalyst using the $\mathrm{Fe}_{3} \mathrm{O}_{4} @ \gamma-\mathrm{Al}_{2} \mathrm{O}_{3}$ core-shell structure as support and $\mathrm{KOH}$ as active component. The catalytic efficiency this magnetic catalyst was indicated from the high biodiesel yield (97.4\%) which was achieved under specific optimum reaction conditions through transesterification of canola oil.

Moreover, several acid-functionalized magnetic nanomaterials have been successfully developed and used in the production of biodiesel from wide range of feedstocks. Zillillah et al. [107] synthesized promising, highly catalytic and recyclable magnetic nano-size solid acid catalyst (HPW-PGMA-MNPs). The core of this catalysts was consist of iron oxide magnetic nanoparticles (MNPs) consist of MNPs poly (glycidyl methacrylate) (PGMA) in present in the form of the shell of this catalyst, and phosphotungstic acid (HPW) was used as the surface acid group. Further, the developed HPW-PGMA-MNPs catalyst was used for transformation of waste grease to biodiesel (i.e., FAMEs) via simultaneous esterification of free fatty acids (FFAs) and transesterification of triglycerides with methanol. A considerably high yield of FAMEs (98\%) was achieved using this magnetic catalyst at optimum reaction conditions. An easy recovery of HPW-PGMA-MNPs catalyst and their reuse for multiple reaction cycles was promising which was indicated from the $95 \%$ productivity of FAMEs after the 10th reaction cycle. Wang et al. [74] 
synthesized acid-functionalized magnetic nanoparticles and used them as heterogeneous nanocatalysts for the production of biodiesel from waste cooking oil as illustrated in Figure 4. Here, acid functionalized, i.e., sulfamic and sulfonic silica-coated crystalline $\mathrm{Fe} / \mathrm{Fe}_{3} \mathrm{O}_{4}$ core/shell magnetic nanoparticles were prepared and their catalytic performance was demonstrated for transesterification of glyceryl trioleate. The results obtained showed that both acid-functionalized nanocatalysts showed promising catalytic performance. However, the sulfamic acid-functionalized nanocatalysts showed comparatively higher activity than the sulfonic acid-functionalized nanocatalysts.
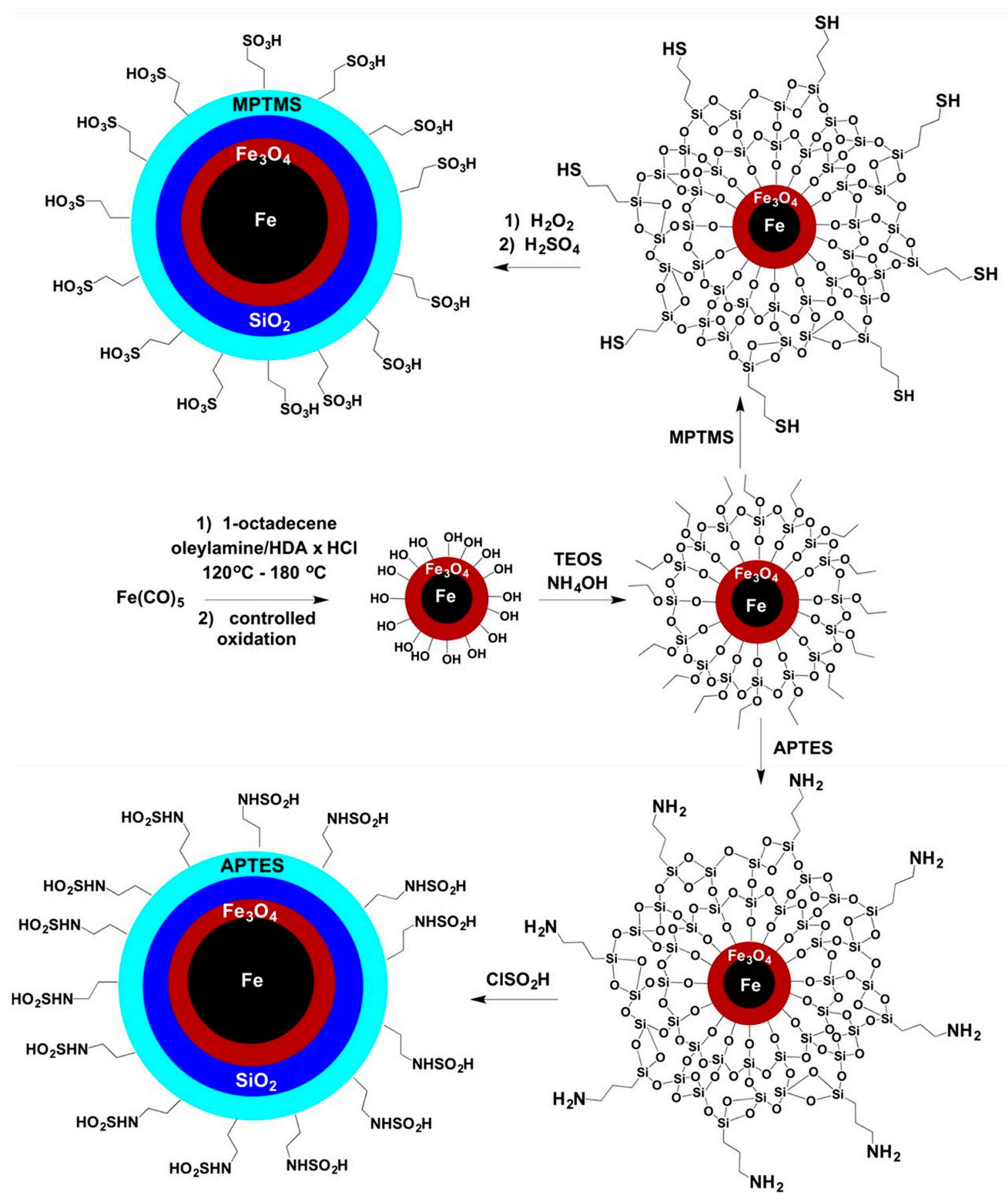

Figure 4. Synthesis of sulfonic acid functionalized magnetic nanoparticles and sulfamic acid functionalized magnetic nanoparticles (adapted from Wang et al. [74] with copyright permission from the American Chemical Society). 
Erdem et al. [108] proposed the novel approach for the surface modification of magnetic iron oxide nanoparticles by silica layer via Stöber method followed by functionalization of chlorosulfonic acid. Thus, developed acid-functionalized magnetic nanoparticles were as potent nanocatalyst in biodiesel production. Further, the catalytic activity of the coated and non-coated solid (acids-functionalized) nanocatalyst was evaluated in palmitic acid-methanol esterification which is one of the common industrial process for biodiesel synthesis. Authors reported that the application of a silica layer on the surface of magnetic nanoparticles creates a minor obstacle with respect to magnetism, but it showed accelerated mass transportation due to its relatively porous structure and magnetic core found to be more stable in the acidic reaction medium by means of covering process. Due to its properties, the developed acid-functionalized nanocatalyst showed promising acid catalyzed esterification. Apart from above discussed reports, there are some other reports are also available which all proposed that development of magnetic nano-size solid acid catalyst will be potentially useful for the green and economic production of biodiesel from various feedstocks. All the reports discussed above demonstrated different advantages of nanocatalysts over other traditional heterogeneous catalysts. The application of nanocatalysts particularly, magnetic nanocatalysts, is of great importance as far as production of biodiesel through heterogeneous catalysis is concerned. Because of their strong magnetic properties, magnetic nanocatalysts can be reused for multiple cycles of transesterification which ultimately reduce the cost involved in the production of biodiesel and make the process economically viable. Moreover, nanocatalysts can works at ambient operational conditions and hence, catalytic processes involving the use of nanocatalysts becomes more easy and convenient.

\section{Conclusions and Future Directions}

Biodiesel is considered one of the most promising alternative fuel to diesel. Biodiesel is a clean and renewable fuel unlike conventional diesel which is non-renewable and cause harmful greenhouse gas emissions. Renewable feedstock such as oils from plant seeds, animal fat, microorganism and algae are the primary sources of biodiesel. It is basically produced via catalytic transesterification carried out by homogeneous or heterogeneous catalysts. Alkaline catalysts such as potassium hydroxide, sodium hydroxide is mainly used in transesterification process of fat. However, these catalysts cause difficulty in transesterification of low-quality feedstock. Therefore, heterogeneous catalysts (i.e., lipase, solid catalysts) are in demand in order to overcome the challenges linked with homogeneous catalysts. Among different heterogeneous catalysts, nanocatalysts in the form of metal oxide based nanocatalysts, nanohydrotalcites, zeolites/nanozeolites, and magnetic nanocatalysts are considered promising catalysts in production of biodiesel from a variety of feedstocks with high yield and better selectivity. Heterogeneous catalysts facilitate the simple and fast recovery of products and sub-products from the reaction mixture. Nanomaterial-based catalysis has the potential to revolutionize the biodiesel production at industrial growth augmenting the biorefineries.

Although heterogeneous catalysis is considered as a promising approach among the various approaches available for transesterification of fatty acids, there is a huge potential to further develop this concept. It can be achieved through the improvement of various factors associated with it such as type of catalyst and reactor configuration. It is possible to develop a modified catalyst and reactor symmetry which can easily work under various dynamic operation conditions. It will collectively lead to the development of an improved design of catalytic processes which are in association with the changing demands of this sector. In this context, it is believed that nanocatalysts developed in recent years are the most appropriate catalysts for heterogeneous catalysis because they possess many advantages including to enhance the efficiency of conventional heterogeneous catalysis approach. However, toxicological concerns of nanocatalysts is the topic of debate and need intensive research to overcome the toxicity effects. There are mixed opinions about the toxicity of nanocatalysts used in biodiesel production, but surely there is a prime necessity of further extensive studies on the evaluation of toxicity of various nanocatalysts used in biodiesel production. In biofuels and biochemicals production, nanocatalysts can play a pivotal role in the improvement of overall productivity. Nanocatalysts, by virtue, have a high 
surface area and catalytic activity, eventually alleviating the problems of mass transfer resistance, fast deactivation and inefficiency. As a whole, the implication of nanocatalysts is not only important for the sustainable biodiesel production but also in production of cellulosic fuels, renewable commodity chemicals and other bio-based products employing the versatile biorefinery platform.

Author Contributions: Conceptualization, A.P.I., A.K.C. and S.S.d.S.; writing-original draft preparation, A.P.I., A.K.C., R.P., S.E.M.; writing-review and editing, A.P.I., A.K.C. and S.S.d.S. All authors have read and agreed to the published version of the manuscript.

Funding: This research received no external funding.

Acknowledgments: A.P.I. is highly thankful to Research Council for the State of Sao Paulo (Fundação de Amparo à Pesquisa do Estado de São Paulo-FAPESP), Brazil providing financial assistance (Process Number-2016/22086-2) in the form of Post-Doctoral Fellowship. A.K.C. is grateful to the Coordenação de Aperfeiçoamento de Pessoal de Nível Superior (CAPES), Brazil, for the financial assistance through visiting professor and researcher program (Process USP number: 15.1.1118.1.0). S.S.S. is thankful to National Council for Scientific and Technological Development (Conselho Nacional de Desenvolvimento Científico e Tecnológico-CNPq) (Process No. 303943/2017-3) and FAPESP (Process No. 2016/10636-8) for research grants.

Conflicts of Interest: Authors do not have any conflict of interest to declare.

\section{References}

1. Perez, V.H.; Junior, E.G.S.; Cubides, C.; David, G.F.; Justo, O.R.; Castro, M.P.P.; Sthel, M.S.; de Castro, H.F. Trends in biodiesel production: Present status and future directions. In Biofuels in Brazil; Springer: Cham, Switzerland, 2014; pp. 281-302.

2. Pohit, S.; Biswas, P.K. India's biodiesel programme: Status, prospects, and shortcomings. In Sustainable Biofuels Development in India; Springer: Cham, Switzerland, 2017; pp. 247-259.

3. Ambat, I.; Srivastava, V.; Sillanpää, M. Recent advancement in biodiesel production methodologies using various feedstock: A review. Renew. Sustain. Energy Rev. 2018, 90, 356-369. [CrossRef]

4. Fjerbaek, L.; Christensen, K.V.; Norddahl, B. A review of the current state of biodiesel production using enzymatic transesterification. Biotechnol. Bioeng. 2009, 102, 1298-1315. [CrossRef] [PubMed]

5. Sharma, Y.C.; Singh, B. Development of biodiesel: Current scenario. Renew. Sustain. Energy Rev. 2009, 13, 1646-1651. [CrossRef]

6. Atadashi, I.M.; Aroua, M.K.; Abdul-Aziz, R.; Sulaiman, N.M.N. The effects of catalysts in biodiesel production: A review. J. Ind. Eng. Chem. 2013, 19, 14-26. [CrossRef]

7. Gardy, J.; Rehan, M.; Hassanpour, A.; Lai, X.; Nizami, A.S. Advances in nano-catalysts based biodiesel production from non-food feedstocks. J. Environ. Manag. 2019, 249, 109316. [CrossRef]

8. de Vasconcellos, A.; Miller, A.H.; Aranda, D.A.G.; Nery, J.G. Biocatalysts based on nanozeolite-enzyme complexes: Effects of alkoxysilane surface functionalization and biofuel production using microalgae lipids feedstock. Colloids Surf. B Biointerfaces 2018, 165, 150-157. [CrossRef]

9. Ramsurn, H.; Gupta, R.B. Nanotechnology in solar and biofuels. ACS Sustain. Chem. Eng. 2013, 1, 779-797. [CrossRef]

10. Jiang, C.; Jia, J.; Zhai, S. Mechanistic understanding of toxicity from nanocatalysts. Int. J. Mol. Sci. 2014, 15, 13967-13992. [CrossRef]

11. Polshettiwar, V.; Varma, R.S. Green chemistry by nano-catalysis. Green Chem. 2010, 12, 743-754. [CrossRef]

12. Christophe, G.; Kumar, V.; Nouaille, R.; Gaudet, G.; Fontanille, P.; Pandey, A.; Soccol, C.R.; Larroche, C. Recent developments in microbial oils production: A possible alternative to vegetable oils for biodiesel without competition with human food? Braz. Arch. Biol. Technol. 2012, 55, 29-46. [CrossRef]

13. Duarte, S.H.; Ghiselli, G.; Maugeri, F. Influence of culture conditions on lipid production by Candida sp. LEB-M3 using glycerol from biodiesel synthesis. Biocatal. Agric. Biotechnol. 2013, 2, 339-343. [CrossRef]

14. Eloka-Eboka, A.C.; Igbum, G.O.; Inambao, F.L. Biodiesel methyl ester production and testing from selected African tropical seed oil feedstocks. Energy Procedia 2017, 142, 755-767. [CrossRef]

15. Gaurav, A.; Dumas, S.; Mai, C.T.Q.; Ng, T.T. A kinetic model for a single step biodiesel production from a high free fatty acid (FFA) biodiesel feedstock over a solid heteropolyacid catalyst. Green Energy Environ. 2019, 4, 328-341. [CrossRef] 
16. Santori, G.; Nicola, G.D.; Moglie, M.; Polonara, F. A review analyzing the industrial biodiesel production practice starting from vegetable oil refining. Appl. Energy 2012, 92, 109-132. [CrossRef]

17. International Energy Agency. Transport Biofuels: Tracking Clean Energy Progress. 2019. Available online: https://www.iea.org/tcep/transport/biofuels/ (accessed on 20 July 2019).

18. Ni, Z.; Li, F.; Wang, H.; Wang, S.; Gao, S. Antioxidative performance and oil-soluble properties of conventional antioxidants in rubber seed oil biodiesel. Renew. Energy 2020, 145, 93-98. [CrossRef]

19. Ahmad, T.; Danish, M.; Kale, P.; Geremew, B.; Adeloju, S.B.; Nizami, M.; Ayoub, M. Optimization of process variables for biodiesel production by transesterification of flaxseed oil and produced biodiesel characterizations. Renew. Energy 2019, 139, 1272-1280. [CrossRef]

20. Sánchez-Arreola, E.; Bach, H.; Hernández, L.R. Biodiesel production from Cascabela ovata seed oil. Bioresour. Technol. Rep. 2019, 7, 100220. [CrossRef]

21. Liu, J.Z.; Cui, Q.; Kang, Y.-F.; Meng, Y.; Gao, M.Z.; Efferth, T.; Fu, Y.J. Euonymus maackii Rupr. Seed oil as a new potential non-edible feedstock for biodiesel. Renew. Energy 2019, 133, 261-267. [CrossRef]

22. Anwar, M.; Rasul, M.G.; Ashwath, N.; Nabi, M.D.N. The potential of utilizing papaya seed oil and stone fruit kernel oil as non-edible feedstock for biodiesel production in Australia: A review. Energy Rep. 2019, 5, 280-297. [CrossRef]

23. Sodamade, A.; Oyedepo, T.A.; Bolaji, O.S. Fatty acids composition of three different vegetable oils (soybean oil, groundnut oil and coconut oil) by high-performance liquid chromatography. Chem. Mater. Res. 2013, 3, 26-30.

24. Predojević, Z.; Škrbić, B.; Đurišić-Mladenović, N. Transesterification of linoleic and oleic sunflower oils to biodiesel using $\mathrm{CaO}$ as a solid base catalyst. J. Serbian Chem. Soc. 2012, 77, 815-832. [CrossRef]

25. Oliveira, M.B.; Barbedo, S.; Soletti, J.I.; Carvalho, S.H.V.; Queimada, A.J.; Coutinho, J.A.P. Liquid-liquid equilibria for the canola oil biodiesel + ethanol + glycerol system. Fuel 2011, 90, 2738-2745. [CrossRef]

26. Martinez-Silveira, A.; Villarreal, R.; Garmendia, G.; Rufo, C.; Vero, S. Process conditions for a rapid in situ transesterification for biodiesel production from oleaginous yeasts. Electron. J. Biotechnol. 2019, 38, 1-9. [CrossRef]

27. Madani, M.; Enshaeieh, M.; Abdoli, A. Single cell oil and its application for biodiesel production. Process Saf. Environ. Protect. 2017, 111, 747-756. [CrossRef]

28. Louhasakul, Y.; Cheirsilp, B.; Maneerat, S.; Prasertsan, P. Potential use of flocculating oleaginous yeasts for bioconversion of industrial wastes into biodiesel feedstocks. Renew. Energy 2019, 136, 1311-1319. [CrossRef]

29. Karatay, S.E.; Demiray, E.; Dönmez, G. Efficient approaches to convert Coniochaeta hoffmannii lipids into biodiesel by in-situ transesterification. Bioresour. Technol. 2019, 285, 121321. [CrossRef]

30. Bagy, M.M.K.; Abd-Alla, M.H.; Morsy, F.M.; Hassan, E.A. Two stage biodiesel and hydrogen production from molasses by oleaginous fungi and Clostridium acetobutylicum ATCC 824. Int. J. Hydrog. Energy 2014, 39, 3185-3197. [CrossRef]

31. Pereira, F.M.; Loures, C.L.A.; Amaral, M.S.; Gomes, F.M.; Pedro, G.A.; Machado, M.A.G.; Reis, C.E.R.; Silva, M.B. Evaluation of fatty acids production by Chlorella minutissima in batch bubble-column photobioreactor. Fuel 2018, 230, 155-162. [CrossRef]

32. Hernández-García, A.; Velásquez-Orta, S.B.; Novelo, B.; Yáñez-Noguez, I.; Monje-Ramírez, I.; Ledesma, M.T.O. Wastewater-leachate treatment by microalgae: Biomass, carbohydrate and lipid production. Ecotoxicol. Environ. Saf. 2019, 174, 435-444. [CrossRef]

33. Kumar, M.; Thakur, I.S. Municipal secondary sludge as carbon source for production and characterization of biodiesel from oleaginous bacteria. Bioresour. Technol. Rep. 2018, 4, 106-113. [CrossRef]

34. Cea, M.; Sangaletti-Gerhard, N.; Acuña, P.; Fuentes, I.; Jorquera, M.; Godoy, K.; Osses, F.; Navia, R. Screening transesterifiable lipid accumulating bacteria from sewage sludge for biodiesel production. Biotechnol. Rep. 2015, 8, 116-123. [CrossRef] [PubMed]

35. Thushari, I.; Babel, S.; Samart, C. Biodiesel production in an autoclave reactor using waste palm oil and coconut coir husk derived catalyst. Renew. Energy 2019, 134, 125-134. [CrossRef]

36. Sakdasri, W.; Sawangkeaw, R.; Ngamprasertsith, S. An entirely renewable biofuel production from used palm oil with supercritical ethanol at low molar ratio. Braz. J. Chem. Eng. 2017, 34, 1023-1034. [CrossRef]

37. Giraçol, J.; Passarini, K.C.; Silva Filho, S.C.; Calarge, F.A.; Tambourgi, E.B.; Santana, J.C.C. Reduction in ecological cost through biofuel production from cooking oils: An ecological solution for the city of Campinas, Brazil. J. Clean. Prod. 2011, 19, 1324-1329. [CrossRef] 
38. Tran, N.N.; Tišma, M.; Budžaki, S.; McMurchie, E.J.; Gonzalez, O.M.M.; Hessel, V.; Ngothai, Y. Scale-up and economic analysis of biodiesel production from recycled grease trap waste. Appl. Energy 2019, 229, 142-150. [CrossRef]

39. Kech, C.; Galloy, A.; Frippiat, C.; Piel, A.; Garot, D. Optimization of direct liquid-liquid extraction of lipids from wet urban sewage sludge for biodiesel production. Fuel 2018, 212, 132-139. [CrossRef]

40. Quah, R.V.; Tan, Y.H.; Mubarak, N.M.; Khalid, M.; Abdullah, E.C.; Nolasco-Hipolito, C. An overview of biodiesel production using recyclable biomass and non-biomass derived magnetic catalysts. J. Environ. Chem. Eng. 2019, 4, 103219. [CrossRef]

41. Knothe, G.; Steidley, K.R. The effect of metals and metal oxides on biodiesel oxidative stability from promotion to inhibition. Fuel Proc. Technol. 2018, 177, 75-80. [CrossRef]

42. Bouaid, A.; Vázquez, R.; Martinez, M.; Aracil, J. Effect of free fatty acids contents on biodiesel quality. Pilot plant studies. Fuel 2016, 174, 54-62. [CrossRef]

43. Kalavathy, G.; Baskar, G. Synergism of clay with zinc oxide as nanocatalyst for production of biodiesel from marine Ulva lactuca. Bioresour. Technol. 2019, 281, 234-238. [CrossRef]

44. Fonseca, J.M.; Teleken, J.G.; de Cinque Almeida, V.; da Silva, C. Biodiesel from waste frying oils: Methods of production and purification. Energy Convers. Manag. 2019, 184, 205-218. [CrossRef]

45. Marchetti, J.M.; Miguel, V.U.; Errazu, A.F. Possible methods for biodiesel production. Renew. Sustain. Energy Rev. 2007, 11, 1300-1311. [CrossRef]

46. Giakoumis, E.G.; Sarakatsanis, C. A comparative assessment of biodiesel cetane number predictive correlations based on fatty acid composition. Energies 2019, 12, 422. [CrossRef]

47. Farobie, O.; Matsumura, Y. State of the art of biodiesel production under supercritical conditions. Prog. Energy Combust. Sci. 2017, 63, 173-203. [CrossRef]

48. Cao, F.; Chen, Y.; Zhai, F.; Li, J.; Wang, J.; Wang, X.; Wang, S.; Zhu, W. Biodiesel production from high acid value waste frying oil catalyzed by superacid heteropolyacid. Biotechnol. Bioeng. 2008, 101, 93-100. [CrossRef]

49. Abukhadra, M.R.; Ibrahim, S.M.; Yakout, S.M.; El-Zaidy, M.E.; Abdeltawab, A.A. Synthesis of Na+ trapped bentonite/zeolite-P composite as a novel catalyst for effective production of biodiesel from palm oil; Effect of ultrasonic irradiation and mechanism. Energy Convers. Manag. 2019, 196, 739-750. [CrossRef]

50. Jung, J.M.; Oh, J.I.; Park, I.K.; Lee, J.; Kwon, E.E. Biodiesel synthesis from fish waste via thermally-induced transesterification using clay as porous material. J. Hazard. Mater. 2019, 371, 27-32. [CrossRef]

51. Li, Z.; Ding, S.; Chen, C.; Qu, S.; Du, L.; Lu, J.; Ding, J. Recyclable Li/NaY zeolite as a heterogeneous alkaline catalyst for biodiesel production: Process optimization and kinetics study. Energy Convers. Manag. 2019, 192, 335-345. [CrossRef]

52. Jeon, Y.; Chi, W.S.; Hwang, J.; Kim, D.H.; Kim, J.H.; Shul, Y.G. Core-shell nanostructured heteropoly acid-functionalized metal-organic frameworks: Bifunctional heterogeneous catalyst for efficient biodiesel production. Appl. Catal. B: Environ. 2018, 242, 51-59. [CrossRef]

53. Hama, S.; Noda, H.; Kondo, A. How lipase technology contributes to evolution of biodiesel production using multiple feedstocks. Curr. Opin. Biotechnol. 2018, 50, 57-64. [CrossRef]

54. Amoah, J.; Ho, S.H.; Hama, S.; Yoshida, A.; Nakanishi, A.; Hasunuma, T.; Ogino, C.; Kondo, A. Converting oils high in phospholipids to biodiesel using immobilized Aspergillus oryzae whole-cell biocatalysts expressing Fusarium heterosporum lipase. Biochem. Eng. J. 2016, 105, 10-15. [CrossRef]

55. Lee, J.H.; Lee, J.H.; Kim, D.S.; Yoo, H.Y.; Park, C.; Kim, S.W. Biodiesel production by lipases co-immobilized on the functionalized activated carbon. Bioresour. Technol. Rep. 2019, 7, 100248. [CrossRef]

56. Zhao, X.; Qi, F.; Yuan, C.; Du, W.; Liu, D. Lipase-catalyzed process for biodiesel production: Enzyme immobilization, process simulation and optimization. Renew. Sustain. Energy Rev. 2015, 44, 182-197. [CrossRef]

57. Fukuda, H.; Hama, S.; Tamalampudi, S.; Noda, H. Whole-cell biocatalysts for biodiesel fuel production. Trends Biotechnol. 2008, 26, 668-673. [CrossRef] [PubMed]

58. Aguieiras, E.C.G.; Cavalcanti-Oliveira, E.D.; Freire, D.M.G. Current status and new developments of biodiesel production using fungal lipases. Fuel 2015, 159, 52-67. [CrossRef]

59. Zhang, X.L.; Yan, S.; Tyagi, R.S.; Surampalli, R.Y. Biodiesel production from heterotrophic microalgae through transesterification and nanotechnology application in the production. Renew. Sustain. Energy Rev. 2013, 26, 216-223. [CrossRef] 
60. Palaniappan, K. An overview of applications of nanotechnology in biofuel production. World Appl. Sci. J. 2017, 35, 1305-1311.

61. Khan, I.; Saeed, K.; Khan, I. Nanoparticles: Properties, applications and toxicities. Arab. J. Chem. 2019, 12, 908-931. [CrossRef]

62. Sudarsanam, P.; Zhong, R.; Van den Bosch, S.; Coman, S.M.; Parvulescu, V.I.; Sels, B.F. Functionalised heterogeneous catalysts for sustainable biomass valorisation. Chem. Soc. Rev. 2018, 47, 8349-8402. [CrossRef]

63. Kumar, D.; Sharma, S.; Srivastava, N.; Shukla, S.; Gaurav, K. Advancement in the utilization of nanocatalyst for transesterification of triglycerides. J. Nanosci. Tech. 2018, 4, 374-379. [CrossRef]

64. Mallesham, B.; Sudarsanam, P.; Reddy, B.M. Production of biofuel additives from esterification and acetalization of bioglycerol over $\mathrm{SnO}_{2}$-based solid acids. Ind. Eng. Chem. Res. 2014, 53, 18775-18785. [CrossRef]

65. Zuliani, A.; Ivars, F.; Luque, R. Advances in nanocatalysts design for biofuels production. ChemCatChem 2018, 10, 1968-1981. [CrossRef]

66. Faria, E.A.; Marques, J.S.; Dias, I.M.; Andrade, R.D.A.; Suareza, P.A.Z.; Prado, A.G.S. Nanosized and reusable $\mathrm{SiO}_{2} / \mathrm{ZrO}_{2}$ catalyst for highly efficient biodiesel production by soybean transesterification. J. Braz. Chem. Soc. 2009, 20, 1732-1737. [CrossRef]

67. Qiu, F.; Li, Y.; Yang, D.; Li, X.; Sun, P. Heterogeneous solid base nanocatalyst: Preparation, characterization and application in biodiesel production. Bioresour. Technol. 2011, 102, 4150-4156. [CrossRef]

68. Madhuvilakku, R.; Piraman, S. Biodiesel synthesis by $\mathrm{TiO}_{2}-\mathrm{ZnO}$ mixed oxide nanocatalyst catalyzed palm oil transesterification process. Bioresour. Technol. 2013, 150, 55-59. [CrossRef]

69. Gardy, J.; Hassanpour, A.; Laia, X.; Ahmed, M.H. Synthesis of $\mathrm{Ti}\left(\mathrm{SO}_{4}\right) \mathrm{O}$ solid acid nano-catalyst and its application for biodiesel production from used cooking oil. Appl. Catal. A Gen. 2016, 527, 81-95. [CrossRef]

70. Gardy, J.; Hassanpour, A.; Laia, X.; Ahmed, M.H.; Rehan, M. Biodiesel production from used cooking oil using a novel surface functionalized $\mathrm{TiO}_{2}$ nano-catalyst. Appl. Catal. B Environ. 2017, 207, 297-310. [CrossRef]

71. Ambursa, M.M.; Ali, T.H.; Voon, L.H.; Sudarsanam, P.; Bhargava, S.K.; Abd-Hamid, S.B. Hydrodeoxygenation of dibenzofuran to bicyclic hydrocarbons using bimetallic $\mathrm{Cu}-\mathrm{Ni}$ catalysts supported on metal oxides. Fuel 2016, 180, 767-776. [CrossRef]

72. Ambursa, M.M.; Sudarsanam, P.; Voon, L.H.; Abd-Hamid, S.B.; Bhargava, S.K. Bimetallic Cu-Ni catalysts supported on MCM-41 and Ti-MCM-41 porous materials for hydrodeoxygenation of lignin model compound into transportation fuels. Fuel Proc. Technol. 2017, 162, 87-97. [CrossRef]

73. Baskar, G.; Gurugulladevi, A.; Nishanthini, T.; Aiswarya, R.; Tamilarasan, K. Optimization and kinetics of biodiesel production from Mahua oil using manganese doped zinc oxide nanocatalyst. Renew. Energy 2017, 103, 641-646. [CrossRef]

74. Wang, H.; Covarrubias, J.; Prock, H.; Wu, X.; Wang, D.; Bossmann, S.H. Acid-functionalized magnetic nanoparticle as heterogeneous catalysts for biodiesel synthesis. J. Phys. Chem. C 2015, 119, 26020-26028. [CrossRef]

75. Alves, M.B.; Medeiros, F.C.M.; Sousa, M.H.; Rubim, J.C.; Suarez, P.A.Z. Cadmium and tin magnetic nanocatalysts useful for biodiesel production. J. Braz. Chem. Soc. 2014, 25, 2304-2313. [CrossRef]

76. Banković-Ilić, I.B.; Miladinović, M.R.; Stamenković, O.S.; Veljković, V.B. Application of nano CaO-based catalysts in biodiesel synthesis. Renew. Sustain. Energy Rev. 2017, 72, 746-760. [CrossRef]

77. Reddy, C.R.V.; Oshel, R.; Verkade, J.G. Room-temperature conversion of soybean oil and poultry fat to biodiesel catalyzed by nanocrystalline calcium oxides. Energy Fuels 2006, 20, 1310-1314. [CrossRef]

78. Yoosuk, B.; Udomsap, P.; Puttasawat, B.; Krasae, P. Modification of calcite by hydration-dehydration method for heterogeneous biodiesel production process: The effects of water on properties and activity. Chem. Eng. J. 2010, 162, 135-141. [CrossRef]

79. Wen, L.; Wang, Y.; Lu, D.; Hu, S.; Han, H. Preparation of KF/CaO nanocatalyst and its application in biodiesel production from Chinese tallow seed oil. Fuel 2010, 89, 2267-2271. [CrossRef]

80. Hu, S.; Wen, L.; Wang, Y.; Zheng, X.; Han, H. Gas-liquid countercurrent integration process for continuous biodiesel production using a microporous solid base KF/CaO as catalyst. Bioresour. Technol. 2012, 123, 413-418. [CrossRef]

81. Zu, Y.; Tang, J.; Zhu, W.; Zhang, M.; Liu, G.; Liu, Y.; Zhang, W.; Jia, M. Graphite oxide-supported CaO catalysts for transesterification of soybean oil with methanol. Bioresour. Technol. 2011, 102, 8939-8944. [CrossRef] 
82. Tahvildari, K.; Anaraki, Y.N.; Fazaeli, R.; Mirpanji, S.; Delrish, E. The study of CaO and MgO heterogenic nano-catalyst coupling on transesterification reaction efficacy in the production of biodiesel from recycled cooking oil. J. Environ. Health Sci. Eng. 2015, 13, 73. [CrossRef]

83. Shekoohi, K.; Hosseini, F.S.; Haghighi, A.H.; Sahrayian, A. Synthesis of some Mg/Co-Al type nano hydrotalcites and characterization. MethodsX 2017, 4, 86-94. [CrossRef]

84. Chelladurai, K.; Rajamanickam, M. Environmentally benign neem biodiesel synthesis using Nano- $\mathrm{Zn}-\mathrm{Mg}-\mathrm{Al}$ hydrotalcite as solid base catalysts. J. Catal. 2014, 2014, 326575. [CrossRef]

85. Deng, X.; Fang, Z.; Liu, Y.H.; Yu, C.L. Production of biodiesel from Jatropha oil catalyzed by nanosized solid basic catalyst. Energy 2011, 36, 777-784. [CrossRef]

86. Dias, A.P.S.; Bernardo, J.; Felizardo, P.; Correia, M.J.N. Biodiesel production over thermal activated cerium modified Mg-Al hydrotalcites. Energy 2012, 41, 344-353. [CrossRef]

87. Obadiah, A.; Kannan, R.; Ravichandran, P.; Ramasubbu, A.; Kumar, S.V. Nano hydrotalcite as a novel catalyst for biodiesel conversion. Dig. J. Nanomater. Biostruct. 2012, 7, 321-327.

88. Woodford, J.J.; Dacquin, J.P.; Wilsona, K.; Lee, A.F. Better by design: Nanoengineered macroporous hydrotalcites for enhanced catalytic biodiesel production. Energy Environ. Sci. 2012, 5, 6145-6150. [CrossRef]

89. Manivannan, R.; Karthikeyan, C. Synthesis of biodiesel from neem oil using Mg-Al nano hydrotalcite. Adv. Mater. Res. 2013, 678, 268-272. [CrossRef]

90. Gao, L.; Teng, G.; Lv, J.; Xiao, G. Biodiesel synthesis catalyzed by the KF/Ca-Mg-Al hydrotalcite base catalyst. Energy Fuels 2010, 24, 646-651. [CrossRef]

91. Prabu, M.; Manikandan, M.; Kandasamy, P.; Kalaivani, P.R.; Rajendiran, N.; Raja, T. Synthesis of biodiesel using the $\mathrm{Mg} / \mathrm{Al} / \mathrm{Zn}$ hydrotalcite/SBA-15 nanocomposite catalyst. ACS Omega 2019, 4, 3500-3507. [CrossRef]

92. Thangaraj, B.; Solomon, P.R.; Muniyandi, B.; Ranganathan, S.; Lin, L. Catalysis in biodiesel production-A review. Clean Energy 2019, 3, 2-23. [CrossRef]

93. Di Serio, M.; Cozzolino, M.; Giordano, M.; Tesser, R.; Patrono, P. From homogeneous to heterogeneous catalysts in biodiesel production. Ind. Eng. Chem. Res. 2007, 46, 6379-6384. [CrossRef]

94. Gutiérrez-Ortega, N.; Ramos-Ramírez, E.; Serafín-Muñoz, A.; Zamorategui-Molina, A.; Monjaraz-Vallejo, J. Use of $\mathrm{Co} / \mathrm{Fe}$-mixed oxides as heterogeneous catalysts in obtaining biodiesel. Catalysts 2019, 9, 403. [CrossRef]

95. Al-Ani, A.; Darton, R.J.; Sneddon, S.; Zholobenko, V. Nanostructured zeolites: The introduction of intracrystalline mesoporosity in basic Faujasite-type catalysts. ACS Appl. Nano Mater. 2018, 1, 310-318. [CrossRef]

96. Kim, K.H.; Lee, O.K.; Lee, E.Y. Nano-immobilized biocatalysts for biodiesel production from renewable and sustainable resources. Catalysts 21018, 8, 68. [CrossRef]

97. Al-Ani, A.; Mordvinova, N.E.; Lebedev, O.I.; Khodakov, A.Y.; Zholobenko, V. Ion-exchanged zeolite P as a nanostructured catalyst for biodiesel production. Energy Rep. 2019, 5, 357-363. [CrossRef]

98. Saeedi, M.; Fazaeli, R.; Aliyan, H. Nanostructured sodium-zeolite imidazolate framework (ZIF-8) doped with potassium by sol-gel processing for biodiesel production from soybean oil. J. Sol-Gel Sci. Technol. 2016, 77, 404-415. [CrossRef]

99. Amalia, S.; Khalifah, S.N.; Baroroh, M.; Muiz, A.; Rahmatullah, A.; Aini, N.; Aqli-Hs, M.R.; Umam, M.N.; Isnaini, I.A.; Suryana, R. Biodiesel production from castor oil using heterogeneous catalyst KOH/Zeolite of natural zeolite Bandung Indonesia. AIP Conf. Proc. 2019, 2120, 080016. [CrossRef]

100. Brito, A.; Borges, M.E.; Otero, N. Zeolite $Y$ as a heterogeneous catalyst in biodiesel fuel production from used vegetable oil. Energy Fuels 2007, 21, 3280-3283. [CrossRef]

101. Hassani, M.; Najafpour, G.D.; Mohammadi, M.; Rabiee, M. Preparation, characterization and application of zeolite-based catalyst for production of biodiesel from waste cooking oil. J. Sci. Ind. Res. 2014, 73, 129-133.

102. $\mathrm{Hu}, \mathrm{S}$; Guan, Y.; Wang, Y.; Han, H. Nano-magnetic catalyst $\mathrm{KF} / \mathrm{CaO}-\mathrm{Fe}_{3} \mathrm{O}_{4}$ for biodiesel production. Appl. Energy 2011, 88, 2685-2690. [CrossRef]

103. Feyzi, M.; Norouzi, L. Preparation and kinetic study of magnetic $\mathrm{Ca} / \mathrm{Fe}_{3} \mathrm{O}_{4} @ \mathrm{SiO}_{2}$ nanocatalysts for biodiesel production. Renew. Energy 2016, 94, 579-586. [CrossRef]

104. Alaei, S.; Haghighi, M.; Toghiani, J.; Vahid, B.R. Magnetic and reusable $\mathrm{MgO} / \mathrm{MgFe}_{2} \mathrm{O}_{4}$ nanocatalyst for biodiesel production from sunflower oil: Influence of fuel ratio in combustion synthesis on catalytic properties and performance. Ind. Crops Prod. 2018, 117, 322-332. [CrossRef]

105. Salimi, Z.; Hosseini, S.A. Study and optimization of conditions of biodiesel production from edible oils using $\mathrm{ZnO} / \mathrm{BiFeO}_{3}$ nano magnetic catalyst. Fuel 2019, 239, 1204-1212. [CrossRef] 
106. Ghalandari, A.; Taghizadeh, M.; Rahmani, M. Statistical optimization of the biodiesel production process using a magnetic core-mesoporous shell $\mathrm{KOH} / \mathrm{Fe}_{3} \mathrm{O}_{4} @ g-\mathrm{Al}_{2} \mathrm{O}_{3}$ nanocatalyst. Chem. Eng. Technol. 2019, 42, 89-99. [CrossRef]

107. Zillillah Ngu, T.A.; Li, Z. Phosphotungstic acid-functionalized magnetic nanoparticles as an efficient and recyclable catalyst for the one-pot production of biodiesel from grease via esterification and transesterification. Green Chem. 2014, 16, 1202. [CrossRef]

108. Erdem, S.; Erdem, B.; Öksüzoğlu, R.M. Magnetic nano-sized solid acid catalyst bearing sulfonic acid groups for biodiesel synthesis. Open Chem. 2018, 16, 923-929. [CrossRef]

(C) 2020 by the authors. Licensee MDPI, Basel, Switzerland. This article is an open access article distributed under the terms and conditions of the Creative Commons Attribution (CC BY) license (http://creativecommons.org/licenses/by/4.0/). 